\title{
THE APPLICATION THINK TALK WRITE LEARNING MODEL TO IMPROVE COMPOSING SHORT STORIES
}

\author{
Lisbet Hutabarat \\ SMP 10 Bekasi \\ Jl. Raya Padurenan, Mustika Jaya, Kota Bekasi, 17166, Indonesia \\ e-mail: lisbethutabarat64@gmail.com
}

\begin{abstract}
This study aims to apply the think talk write learning model to improve Indonesian learning outcomes in composing short stories in Class IX.1 SMP Negeri 10 Kota Bekasi. The subjects were students of class IX.1 SMP Negeri 10 Kota Bekasi total of 40 students. The method used was classroom action research. Methods of data collection using tests, observations, interview, and documentation. The results obtained by the test result data evaluation of learning that have increased each cycle, the test results obtained pre-cycle average value of 73,30 with mastery learning 47,50\%, which has increased in the cycle I average value of 78,55 with mastery learning $72,50 \%$, which has increased in the cycle II average value of 81,10 with mastery learning $92,50 \%$. The conclusion of this study is through the learning model of think talk write can improve Indonesian learning outcomes subject of compile short stories in class IX.1 SMP Negeri 10 Kota Bekasi
\end{abstract}

Key Words: Indonesian Language, Short Story, Think Talk Write

Article History: Received: 22/09/2020; Revised: 21/10/2020; Accepted: 28/11/2020; Published: 31/12/2020

How to Cite (MLA 7th): Hutabarat, Lisbet. "The Application Learning Model of Think Talk Write to Improve Compile Short Stories." Hortatori Jurnal Pendidikan Bahasa dan Sastra Indonesia 4.2 (2020): 122-126. Print/Online. Copyrights Holder: Lisbet Hutabarat. First Publication: Hortatori Jurnal Pendidikan Bahasa dan Sastra Indonesia (2020).

This work is licensed under a Creative Commons Attribution-ShareAlike 4.0 International License.

\section{Pendahuluan}

Kurikulum pembelajaran sastra secara umum menyebutkan bahwa tujuan pembelajaran sastra di sekolah adalah untuk mengembangkan kepribadian, memperluas wawasan, serta meningkatkan pengetahuan dan kemampuan berbahasa. Seiring tujuan tersebut, pembelajaran sastra seyogyanya dapat mewujudkan empat prinsip agar dapat mengemban fungsinya dengan baik. Keempat prinsip tersebut menurut Gani dalam Warsiman (2016) yaitu: (1) pembelajaran sastra memberikan kebebasan kepada peserta didik untuk menampilkan respon dan reaksinya; (2) pembelajaran sastra memberikan kesempatan kepada peserta didik untuk mempribadikan dan mengkristalisasikan rasa pribadinya pada cipta sastra; (3) pembelajaran sastra memberikan kesempatan kepada guru untuk menemukan butir-butir kontak di antara pendapat para peserta didik; (4) pembelajaran sastra memberikan kesempatan kepada guru untuk mewujudkan fungsinya sebagai motivator terhadap penjelajahan pengaruh vital yang melekat (inheren) di dalam sastra itu sendiri. Pesan tersebut sejalan pesan yang terkandung dalam kurikulum yaitu pembelajaran yang memberikan kesempatan lebih luas kepada peserta didik untuk mengaktualisasikan dirinya.

Salah satu jenis sastra yang diajarkan pada peserta didik di tingkat Sekolah Menengah Pertama adalah cerita pendek (cerpen). Cerpen merupakan suatu genre yang menampilkan kehidupan dan kehidupan itu sendiri adalah satu kenyataan sosial. Kehidupan mencakup hubungan antar masyarakat, antara masyarakat dengan orang-orang, dan antar peristiwa yang terjadi dalam batin seseorang (Asri, 2011). Pembelajaran cerita pendek haruslah melibatkan aktivitas mental untuk memahami dan menyenangi cerpen, meletakkan penghargaan dengan nilai tinggi pada cerpen, menjadi peka terhadap nilai-nilai cerpen, dan menghargai secara kritis terhadap cerpen yang dibacanya (Suwignyo, 2004). 
Fenomena di lapangan menunjukkan bahwa hasil belajar peserta didik pada mata pelajaran bahasa Indonesia khususnya menyusun cerita pendek masih rendah. Peserta didik menganggap pelajaran bahasa Indonesia merupakan pelajaran yang tidak penting dan membosankan. Salah satu kesulitan belajar bahasa Indonesia menurut peserta didik yaitu karena materinya cenderung banyak bacaan. Kesulitan belajar bahasa Indonesia yang dialami menyebabkan para peserta didik kurang antusias dalam menerima pelajaran. Beberapa permasalahan dalam kegiatan pembelajaran bahasa Indonesia adalah keaktifan peserta didik yang cenderung pasif dan kurang respons ketika guru menyampaikan materi pelajaran. Guru mengalami kesulitan dalam memilih model pembelajaran yang tepat agar peserta didik dapat termotivasi dalam pembelajaran bahasa Indonesia. Rendahnya keaktifan peserta didik dalam kegiatan pembelajaran berpengaruh pada hasil belajar peserta didik yang masih rendah. Pencapaian hasil belajar mata pelajaran bahasa Indonesia, ditunjukkan dari nilai rata-rata kelas yang masih di bawah kriteria ketuntasan minimal yang ditetapkan yaitu 76,00 dan jika dilihat dari ketuntasan klasikal masih di bawah 50\%.

Pembelajaran sastra di sekolah belum menyentuh kemampuan inferensial, evaluatif, dan apresiatif. Hal itu tidak lepas dari kenyataan umum pembelajaran sastra yang masih berada pada sekitar pembicaraan tentang sastra, menghafal karya, dan pelaksanaan pembelajaran dengan ceramah (Mustakim, 2008). Masalah yang sering terjadi dalam pembelajaran sastra di sekolah adalah guru belum mampu membuka mata para peserta didik terhadap daya tarik sastra. Pembelajaran sastra telah jauh membawa anak dengan berbagai kegiatan yang serta merta dapat menjenuhkan dan membosankan, bahkan dapat menimbulkan kebencian peserta didik terhadap sastra (Atmazaki, 2007).

Tindakan perbaikan pembelajaran untuk mengatasi permasalahan pembelajaran sastra pada penelitian ini adalah melalui penerapan model pembelajaran think talk write. Model pembelajaran think talk write pada dasarnya dibangun melalui kegiatan berpikir, berbicara, dan menulis. Alur kemajuan strategi think talk write dimulai dari keterlibatan peserta didik dalam berpikir atau berdialog dengan dirinya sendiri setelah proses membaca, selanjutnya berbicara dan membagi ide (sharing) dengan temanya sebelum menulis (Chotimah dan Fathurrohman, 2018).

Berdasarkan permasalahan tersebut, maka rumusan masalah dalam penelitian ini adalah bagaimana penerapan model pembelajaran think talk write untuk meningkatkan hasil belajar bahasa Indonesia materi menyusun cerita pendek pada peserta didik kelas IX.1 SMP Negeri 10 Kota Bekasi. Penelitian tindakan kelas ini diharapkan berguna untuk mengembangkan model pembelajaran, sehingga dapat dijadikan alternatif pilihan model pembelajaran pada mata pelajaran bahasa Indonesia.

\section{Metode}

Metode penelitian ini adalah Penelitian Tindakan Kelas (PTK) atau Classroom Action Research (CAR). Penelitian tindakan kelas merupakan proses pengkajian masalah pembelajaran di dalam kelas melalui refleksi diri dalam upaya untuk memecahkan masalah tersebut dengan cara melakukan berbagai tindakan yang terencana dalam situasi nyata serta menganalisis setiap pengaruh dari perlakuan tersebut (Sanjaya, 2009). Desain penelitian yang digunakan adalah model Kurl Lewin, yang menguraikan empat komponen proses tindakan, yaitu: perencanaan (planning), tindakan (acting), pengamatan (observing), dan refleksi (reflecting). Subjek penelitian yaitu peserta didik kelas IX.1 SMP Negeri 10 Kota Bekasi berjumlah 40 peserta didik, terdiri dari 20 laki-laki dan 20 perempuan. Penelitian dilaksanakan di SMP Negeri 10 Kota Bekasi pada Semester I Tahun Pelajaran 2019/2020 tepatnya bulan Oktober sampai dengan November 2019.

Teknik pengumpulan data penelitian menggunakan tes tertulis, lembar observasi, wawancara, dan metode dokumentasi. Bentuk tes yang digunakan yaitu tes menulis cerita pendek dengan kriteria penilaian meliputi enam unsur, yaitu: (1) tema, (2) alur/plot, (3) latar/setting, (4) sudut pandang, (5) gaya bahasa, (6) tokoh dan penokohan. Analisis data penelitian dilakukan dengan menggunakan teknik statistik sederhana yaitu dengan menggunakan analiasis deskriptif. Analisis deskriptif adalah model analisis dengan cara membandingkan rata-rata persentasenya. Analisis yang digunakan secara umum terdiri dari proses analisis untuk mengetahui tingkat hasil belajar peserta didik.

\section{Hasil dan Diskusi}

Penelitian tindakan kelas ini terdiri dari dilaksanakan melalui tiga tahapan, yaitu tahap Pra Siklus, Siklus I dan Siklus II. Pra Siklus dilaksanakan sebelum diberikan perlakuan pembelajaran melalui model pembelajaran think talk write. Tes Pra Siklus yang digunakan sebagai tolak ukur perbandingan 
keberhasilan pembelajaran sebelum dilakukan tindakan dengan setelah dilakukan tindakan. Hasil tes Pra Siklus sebagai berikut:

Tabel 1. Hasil Belajar Pra Siklus

\begin{tabular}{ccccc}
\hline Interval & Frekuensi & Persentase (\%) & Keterangan \\
\hline $56-65$ & & 5 & 12,50 & Belum Tuntas \\
$66-75$ & & 16 & 40,00 & Belum Tuntas \\
$76-85$ & 19 & 47,50 & Tuntas \\
$86-100$ & & - & 73,30 & - \\
& Rata-rata & & & $47,50 \%$ \\
\hline
\end{tabular}

Nilai rata-rata yang diperoleh mencapai 73,30 yang masih di bawah kriteria ketuntasan minimal yang ditetapkan yaitu 76,00. Hasil tes pra siklus, peserta didik yang tuntas sebanyak 19 peserta didik atau $47,50 \%$ dan peserta didik yang belum tuntas sebanyak 21 peserta didik atau 52,50\%. Hasil tersebut menunjukkan bahwa hasil belajar peserta didik pada mata pelajaran Bahasa Indonesia masih rendah. Rendahnya hasil belajar peserta didik disebabkan oleh motivasi dan minat peserta didik dalam kegiatan pembelajaran Bahasa Indonesia di kelas masih rendah dan kurangnya inovasi dari guru bahasa Indonesia dalam kegiatan pembelajaran bahasa Indonesia. Oleh karena itu, perlu ada perbaikan pembelajaran melalui penelitian tindakan kelas.

Pelaksanaan pembelajaran pada Siklus I dan Siklus II, masing-masing terdiri dari dua kali pertemuan, yang masing-masing pertemuan dengan alokasi waktu $2 \times 40$ menit. Tiap pertemuan pembelajaran pada prinsipnya sebagai berikut:

Pada kegiatan pendahuluan, guru membuka pelajaran dengan salam dan menanyakan kabar serta dilanjutkan dengan berdoa. Guru mencatat kehadiran peserta didik, guru memberikan apersepsi dan motivasi. Guru menyampaikan tujuan dan topik pembelajaran sesuai dengan kompetensi dasar yang ingin dicapai. Pada kegiatan inti, guru membagi kelas menjadi 8 kelompok, setiap kelompok terdiri dari 5 peserta didik. Guru membagikan lembar kerja berupa teks bacaan tentang menyusun cerita pendek. Guru membacakan petunjuk dan prosedur pelaksanaan dalam mengerjakan lembar kerja. Peserta didik membaca teks bacaan yang diberikan guru, selanjutnya peserta didik membuat catatan kecil dari hasil bacaan secara individu (think). Peserta didik berdiskusi bersama teman kelompoknya untuk membahas isi catatan pada teks bacaan (talk). Semua peserta didik secara bergiliran diberi kesempatan untuk maju mempresentasikan hasil diskusi. Peserta didik mengonstruksi pengetahuan hasil diskusi dalam bentuk tulisan dengan bahasannya sendiri (write). Guru mengarahkan pemahaman konsep peserta didik yang masih kurang tepat. Guru memberi penguatan terhadap materi yang telah disampaikan. Pada kegiatan akhir, peserta didik dibantu oleh guru membuat kesimpulan dari hasil kegiatan pembelajaran. Guru menguji pemahaman peserta didik terhadap materi yang telah disampaikan dengan tanya jawab dan pelajaran ditutup dengan doa dan salam.

Data aktivitas belajar peserta didik pada Siklus I menunjukkan bahwa belum terjadi peningkatan aktivitas belajar peserta didik yang maksimal. Hal ini ditandai dari 12 aspek aktivitas yang diamati, ada beberapa aspek yang dalam kriteria rendah. Setelah dilakukan observasi terhadap hasil aktivitas belajar peserta didik yang diperoleh bahwa pada Siklus I terdapat kendala yang menyebabkan nilai rata-rata kelas di bawah batas minimal. Data hasil observasi aktivitas belajar pada Siklus II, menunjukkan adanya peningkatan. Disimpulkan bahwa pada Siklus II rata-rata peserta didik lebih aktif dan antusias mengikuti pembelajaran sehingga berada pada kategori sangat baik mencapai $86,04 \%$. Aktivitas peserta didik dalam pembelajaran sangat diperlukan karena tanpa aktivitas peserta didik, pembelajaran tidak akan berarti.

Hasil analisis data diperoleh data hasil belajar peserta didik, bahwa pada Siklus II mengalami peningkatan ketuntasan belajar dibandingkan Siklus I. Hal ini pada Siklus II mengalami perbaikan proses pembelajaran, sehingga peserta didik lebih mudah memahami materi yang disampaikan guru.

Tabel 2. Rekapitulasi Hasil Belajar

\begin{tabular}{|c|c|c|c|}
\hline Hasil Pos Test & Pra Siklus & Siklus I & Siklus II \\
\hline Rata-rata & 73,30 & 78,55 & 81,10 \\
\hline Ketuntasan & $47,50 \%$ & $72,50 \%$ & $92,50 \%$ \\
\hline
\end{tabular}


Dari tabel di atas dapat digambarkan dalam bentuk diagram hasil belajar berdasarkan nilai ratarata kelas sebagai berikut:

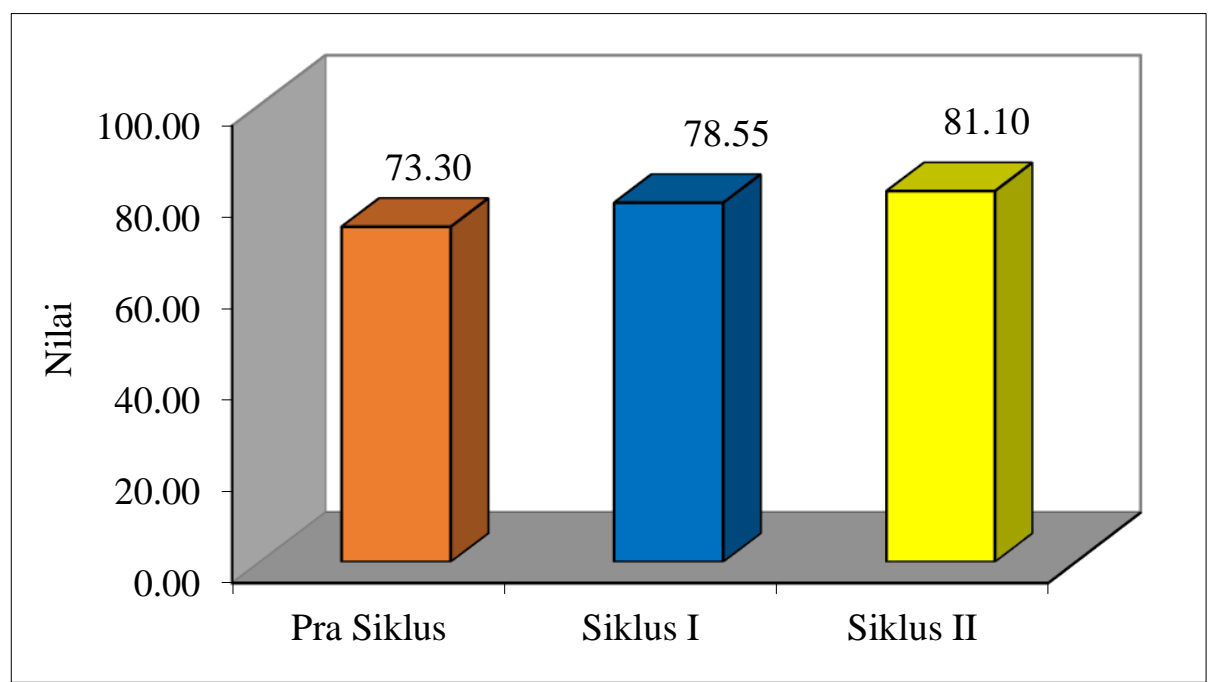

Gambar 1. Hasil Belajar Peserta Didik Berdasarkan Nilai Rata-rata Kelas

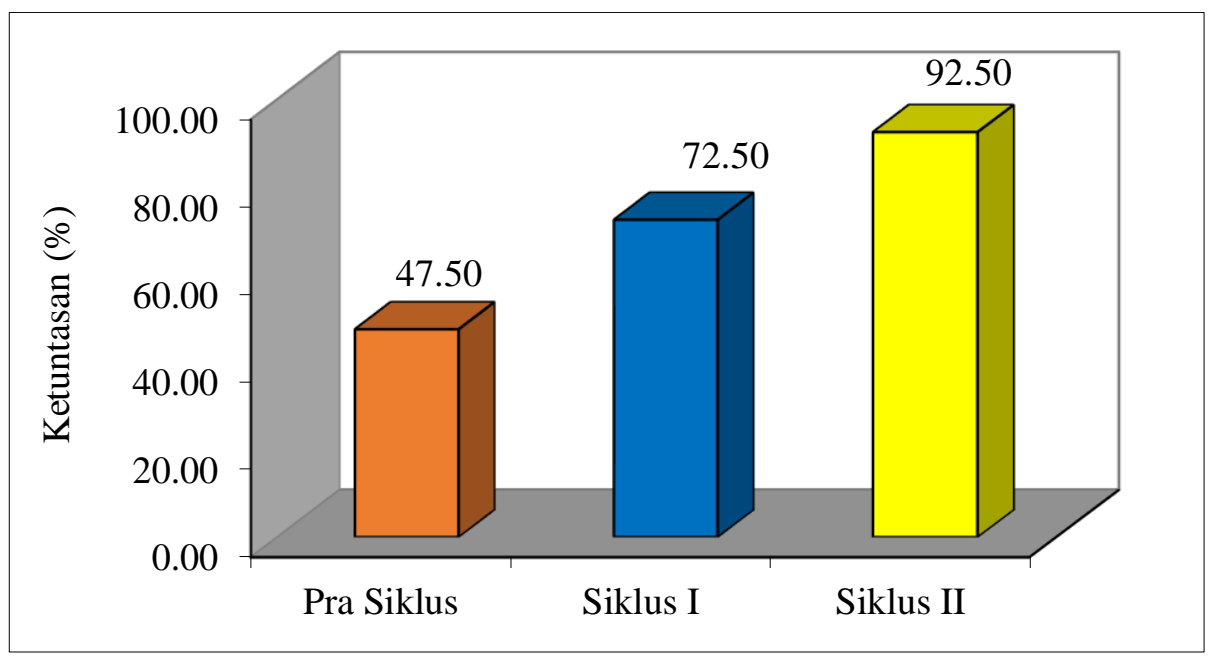

Gambar 2. Hasil Belajar Peserta Didik Berdasarkan Ketuntasan Klasikal

Data hasil belajar peserta didik berdasarkan nilai rata-rata dan ketuntasan belajar klasikal, pada Pra Siklus diperoleh nilai rata-rata 73,30 dengan tingkat ketuntasan belajar klasikal 47,50\%. Pada Siklus I diperoleh nilai rata-rata 78,55 dengan ketuntasan belajar klasikal mencapai 72,50\%, kemudian pada Siklus II nilai rata-rata 81,10 dan ketuntasan belajar mencapai $92,50 \%$. Hal ini terlihat pada setiap siklusnya mengalami peningkatan. Adanya peningkatan hasil belajar peserta didik dari Siklus I ke Siklus II juga didukung oleh data-data lain yang juga mengalami peningkatan, yaitu meliputi: data observasi kinerja guru dalam proses pembelajaran, data angket respons peserta didik dan data wawancara langsung dengan peserta didik.

Hasil penelitian menunjukkan bahwa model pembelajaran think talk write digunakan sebagai salah satu alternatif suatu model mengajar untuk meningkatkan aktivitas dan hasil belajar peserta didik pada materi menyusun cerita pendek kelas IX.1 SMP Negeri 10 Kota Bekasi. Hasil penelitian ini didukung pendapat Sanjaya (2015), bahwa model pembelajaran think talk write dapat meningkatkan peran aktif peserta didik dan hasil belajar peserta didik. Peningkatan peran aktif terjadi di semua tahapan model pembelajaran think talk write, yaitu tahapan think yang dilalui dengan proses membaca dan membuat catatan kecil, tahapan talk ketika peserta didik saling berdiskusi membahas isi catatannya dan presentasi hasil diskusi, serta tahapan write pada saat mengonstruksi pengetahuan hasil diskusi dengan bahasa sendiri. Penerapan model pembelajaran think talk write dalam kegiatan pembelajaran memiliki 
beberapa kelebihan diantaranya aktivitas think dapat meningkatkan keterampilan peserta didik dalam membedakan dan mempersatukan ide yang disajikan dalam teks bacaan melalui aktivitas membaca terlebih dahulu, aktivitas talking dapat membantu guru mengetahui tingkat pemahaman peserta didik, dan aktivitas write dapat meningkatkan keterampilan berpikir dan menulis (Yamin dan Ansari, 2008).

\section{Simpulan}

Kesimpulan penelitian ini adalah pembelajaran melalui model pembelajaran think talk write dapat meningkatkan hasil belajar Bahasa Indonesia materi menyusun cerita pendek di kelas IX.1 SMP Negeri 10 Kota Bekasi. Penggunaan model pembelajaran think talk write dapat meningkatkan aktivitas belajar peserta didik. Hal ini ditunjukkan dari data hasil lembar observasi setiap siklusnya yang mengalami peningkatan, yaitu pada siklus I diperoleh rata-rata skor sebesar 73,18\% yang mengalami peningkatan pada siklus II dengan diperoleh rata-rata skor sebesar $87,50 \%$. Peningkatan aktivitas peserta didik dalam kegiatan pembelajaran dikarenakan kinerja guru dalam melaksanakan kegiatan pembelajaran juga mengalami peningkatan pada tiap siklusnya. Hasil belajar peserta didik pada pra siklus diperoleh nilai rata-rata kelas sebesar 73,30 dengan ketuntasan klasikal 47,50\%, mengalami peningkatan pada siklus I dengan diperoleh nilai rata-rata kelas menjadi 78,55 dengan ketuntasan klasikal 72,50\%, yang mengalami peningkatan kembali pada siklus II dengan diperoleh nilai rata-rata kelas menjadi 81,10 dengan ketuntasan klasikal sebesar 92,50\%. Model pembelajaran think talk write dapat dijadikan sebagai pilihan model pembelajaran pada mata pelajaran bahasa Indonesia khususnya materi menyusun cerita pendek. Melalui model pembelajaran think talk write, pembelajaran lebih menyenangkan sehingga dapat meningkatkan motivasi dan keaktifan peserta didik dalam mengikuti kegiatan pembelajaran yang berdampak positif terhadap peningkatan hasil belajar peserta didik.

\section{Ucapan Terima Kasih}

Penelitian ini dapat terselesaikan atas dukungan dan bantuan dari berbagai pihak. Oleh karena itu, peneliti mengucapkan terima kasih, khususnya kepada Ibu Nurleli Ismael, M.Pd, Kepala SMP Negeri 10 Kota Bekasi yang memberikan dukungan dan motivasi kepada peneliti dalam pelaksanaan penelitian ini; Ibu Nurhijriati, S.Pd, selaku kolaborator yang membantu dan berperan serta dalam penelitian ini; rekanrekan guru di SMP Negeri 10 Kota Bekasi yang memberikan dukungan dan motivasi kepada peneliti dalam pelaksanaan penelitian ini; peserta didik kelas IX.1 SMP Negeri 10 Kota Bekasi yang telah menjadi subjek dalam penelitian ini; dan keluarga peneliti yang selalu mendoakan, memotivasi dan memberi kesempatan kepada peneliti untuk selalu bekerja demi kemajuan pendidikan.

\section{Daftar Rujukan}

Asri, Y. “Analisis Sosiologis Cerpen Si Padang Karya Harris Effendi Thahar”. Humaniora. 23 (3): 245255, 2011.

Atmazaki. Ilmu Sastra: Teori dan Terapan. Padang: Universitas Negeri Padang Press, 2007.

Chotimah, Chusnul, dan Muhammad Fathurrohman. Paradigma Baru Sistem Pembelajaran dari Teori, Metode, Model, Media, Hingga Evaluasi Pembelajaran. Yogyakarta: Ar-Ruzz Media, 2018.

Mustakim. Psikologi Pendidikan. Semarang: Pustaka Pelajar, 2008.

Sanjaya, Wina. Pembelajaran dalam Implementasi Kurikulum Berbasis Kompetensi. Jakarta: Kencana, 2015.

Sanjaya, Wina. Penelitian Tindakan Kelas. Jakarta: Kencana Prenada Media Group, 2009.

Suwignyo, H. "Profil dan Perencanaan Pembelajaran Prosa Fiksi di Sekolah Menengah". Vokal. 1(5): 5969, 2004.

Warsiman. Membumikan Pembelajaran Sastra yang Humanistik. Malang: UB Press, 2016.

Yamin, Martins, dan Bansu I. Ansari. Taktik Mengembangkan Kemampuan Individual Siswa. Jakarta: Gaung Persada Press, 2008. 